\title{
ANALISIS FAKTOR-FAKTOR YANG BERHUBUNGAN DENGAN KEJADIAN STATUS GIZI PADA IBU HAMIL DI WILAYAH KERJA PUSKESMAS WINONG I KABUPATEN PATI
}

\author{
Lely Indriasari ${ }^{1)}$, Sifa Altika ${ }^{2}$, Sri Hadi Sulistiyaningsih ${ }^{3)}$ \\ ${ }^{1}$ Prodi D III Kebidanan, Stikes Bakti Utama Pati \\ ${ }^{2}$ Prodi D III Kebidanan, Stikes Bakti Utama Pati \\ ${ }^{3}$ Prodi Sarjana Kebidanan, Stikes Bakti Utama Pati \\ Email: sifa.altika@gmail.com
}

\begin{abstract}
ABSTRAK
Ibu hamil dan menyusui merupakan dua kelompok sasaran yang sangat perlu mendapat perhalian khusus dalam penerapan Pedoman Unium Gizi Seimbang (PUGS). Data menunjukkan bahwa sepertiga $(35,65 \%)$ wanita usia subur (WUS) menderita Kurang Energi Kronis (KEK). Ibu hamil membutuhkan energi dan zat-zat gizi lebih banyak dari pada wanita tidak hamil. Untuk memenuhi kebutuhan tersebut ibu hamil harus makan makanan dengan gizi seimbang.

Jenis penelitian yang digunakan adalah explanatory research dengan metode pendekatan cross sectional.populasi dan sampel adalah ibu hamil yang berjumlah 42 orang diambil dengan menggunakan metode Total sampling. Uji analisis menggunakan metode Chi-Square.

Hasil penelitian diketahui bahwa Ibu hamil yang berpengetahuan kurang sebanyak 5 orang $(11,9 \%)$, berpengetahuan sedang sebanyak 26 orang $(61,9 \%)$, dan berpengetahuan baik sebanyak 11 orang $(26,2 \%)$. Budaya yang tidak mendukung sebanyak 12 orang $(28,6 \%)$, yang kurang mendukung sebanyak 25 orang $(59,5 \%)$ dan yang mendukung sebanyak 5 orang $(11,9 \%)$. Keluarga ibu hamil yang berpendapatan <437.500 sebanyak 10 orang $(23,8 \%)$. Yang berpendapatan $437.500-1.000 .000$ sebanyak 23 orang $(54,8 \%)$ dan yang berpendapatan $>1.000 .000$ sebanyak 9 orang $(21,4 \%)$. Kejadian KEK di Wilayah Kerja Puskesmas Winong I Kabupaten Pati terjadi KEK sebanyak 8 orang (19\%), dan yang normal sebanyak 34 orang (81\%). Tidak ada hubungan antara Kategori Budaya dengan KEK di Wilayah Kerja Puskesmas Winong I Kabupaten Pati Tahun 2009 (p value $=0,867>0,05$ ). Ada hubungan antara Kategori Pengetahuan dengan KEK di Wilayah Kerja Puskesmas Winong I Kabupaten Pati ( $\mathrm{p}$ value $=0,000<0,05)$. Ada hubungan antara Pendapatan Keluarga dengan KEK di Wilayah Kerja Puskesmas Winong I Kabupaten Pati Tahun 2009 (p value $=0,012<0,05$ ).

Kata kunci: Pengetahan, budaya, pendapatan keluarga dan KEK
\end{abstract}

\begin{abstract}
Pregnant and lactating women are two target groups that really need special attention in the application of the Guidelines for Balanced Nutrition Unium (PUGS). Data shows that one third (35.65\%) of women of childbearing age (WUS) suffer from Chronic Energy Deficiency (KEK). Pregnant women need energy and nutrients more than non-pregnant women. To meet these needs pregnant women must eat foods with balanced nutrition.

This type of research is explanatory research with a cross sectional approach method. The population and samples are 42 pregnant women who were taken using the total sampling method. Test analysis using the Chi-Square method.

The results showed that there were 5 pregnant women (11.9\%) who had poor knowledge, 26 people (61.9\%) had moderate knowledge, and 11 people (26.2\%) who had good knowledge. There were 12 nonsupportive cultures (28.6\%), 25 people (59.5\%) less supportive, and 5 people (11.9\%) that supported. 10 families of pregnant women with income $<437,500$ (23.8\%). Those with an income of 437,500 1,000,000 were 23 people (54.8\%) and those with an income> 1,000,000 were 9 people (21.4\%). The KEK incidence in the Winong I Public Health Center, Pati Regency, occurred as many as 8 people (19\%) and 34 people (81\%) who were normal. There is no relationship between the Culture Category and KEK in the Work Area of Winong I Public Health Center, Pati Regency in 2009 ( $p$ value $=0.867$ ) 0.05). There is a relationship between the Knowledge Category and KEK in the Working Area of Winong I Health Center, Pati Regency ( $p$ value $=0.000<0.05$ ). There is a relationship between family income and KEK in the working area of Winong I Public Health Center, Pati Regency in 2009 ( $p$ value $=0.012$ $<0.05)$.
\end{abstract}

Keywords: Knowledge, culture, family income and KEK 


\section{PENDAHULUAN}

Ibu hamil dan menyusui merupakan dua kelompok sasaran yang sangat perlu mendapat perhalian khusus dalam penerapan Pedoman Umum Gizi Seimbang (PUGS). Hal ini berdasarkan pada : 1) masalah gizi banyak dijumpai pada ibu hamil dan menyusui, 2) dampak negatif yang ditimbulkan karena status gizi yang buruk pada ibu hamil dan menyusui tidak hanya mengenai diri yang bersangkutan tetapi juga pada perkembangan janin yang akan dilahirkan serta perkembangan dan pertumbuhan anak dikemudian hari (Depkes RI, 2012).

Data menunjukkan bahwa sepertiga $(35,65 \%)$ wanita usia subur (WUS) menderita Kurang Energi Kronis (KEK). Masalah ini mengakibatkan pada saat hamil akan menghambat pertumbuhan janin sehingga akan menimbulkan resiko pada bayi dengan Berat Badan Lahir Rendah (BBLR) (Depkes RI, 2012).

Wanita yang menderita malnutrisi selama kehamilan atau selama minggu pertama kehamilan cenderung melahirkan bayi yang menderita kerusakan otak dan sumsum tulang, karena system saraf pusat sangat peka pada 2 5 minggu pertama. Ibu menderita malnutrisi sepanjang minggu terakhir kehamilan akan melahirkan bayi dengan berat badan lahir rendah $(<2500$ gram), karena jaringan lemak banyak ditimbun selama trimester III (Arisman, 2012).

Berdasarkan data dari Dinas Kesehatan Kabupaten Pati tahun 2008, jumlah ibu hamil adalah $12.871 \mathrm{ibu}$ hamil, yang mengalami risiko Kurang Energi Kronisk (KEK) di Kabupaten Pati adalah 250 ibu hamil. Kasus Berat Bayj Lahir Rendah (BBLR) di Kabupaten Pati sebanyak 150 bayi (Dinkes Kab. Pati 2018).

Di Wilayah Kerja Puskesmas Winong I tahun 2008 terdapat 234 ibu hamil dengan kejadian Kurang Energi Kronisk (KEK) sebanyak 13 ibu hamil dan 3 kasus Berat Bayi Lahir Rendah (BBLR) (Puskesmas Margorejo, 2008).

Survei pendahuluan dilakukan pada ibu hamil yang memeriksakan kehamilannya di Puskesmas Winong I Kabupaten Pati sebanyak 15 orang diketahui bahwa ibu yang mempunyai pengetahuan baik sebanyak 5 orang (33,3\%), ibu yang mempunyai pengetahuan kurang sebanyak 10 orang $(66, \%)$. Ibu yang pantang makan ikan laut sebanyak 5 orang $(33,3 \%)$, ibu yang makan makanan tanpa berpantang 10 orang $(53,7 \%)$. Ibu yang mempunyai pendapatan keluarga kurang dari UMR sebanyak 6 orang (40\%) dan yang mempunyai pendapatan lebih dari UMR sebanyak 9 orang (60\%).Ibu hamil yang status gizi kurang sebanyak 3 orang ( $20 \%$ ) dan ibu hamil dengan status gizi normal sebanyak 12 orang (80\%) (Data Primer, 2019).

Ibu hamil membutuhkan energi dan zatzat gizi lebih banyak dari pada wanita tidak hamil. Untuk memenuhi kebutuhan tersebut ibu hamil harus makan makanan dengan gizi seimbang. Bahan makanan yang digunakan harus meliputi enam kelompok yaitu makanan yang mengandung protein hewani dan nabati, 
susu dalam olahannya, roti dan biji-hijian, buah dan sayur yang kaya akan vitamin $\mathrm{C}$, sayuran berwarna hijau tua, sayur dan buah lain. Jika keenam bahan makanan ini digunakan, maka seluruh zat gizi yang dibutuhkan oleh wanita hamil akan terpenuhi, kecuali zat besi dan asam folat (Arisman, 2017).

Berdasarkan latar belakang diatas perumusan masalah dalam penelitian ini adalah "Apakah faktor-faktor yang berhubungan dengan kejadian Status Gizi pada Ibu Hamil di Wilayah Kerja Puskesmas Winong I Kabupaten Pati”. Tujuan penelitian ini adalah untuk faktorfaktor yang berhubungan dengan kejadian Status Gizi pada ibu hamil di Wilayah Kerja Puskesmas Winong I Kabupaten Pati.

\section{METODE}

\section{HASIL}

\section{Analisa Univariat}

Table 1

Distribusi Frekuensi Kategori Pengetahuan Responden di Wilayah Kerja Puskesmas Winong I Kabupaten Pati

\begin{tabular}{|c|c|c|c|}
\hline No. & Kategori Pengetahuan & $\mathrm{f}$ & $\%$ \\
\hline 1 & Kurang & 5 & 11,9 \\
\hline 2. & Sedang & 26 & 61,9 \\
\hline \multirow[t]{2}{*}{3.} & Baik & 11 & 26,2 \\
\hline & Jumlah & 42 & 100 \\
\hline
\end{tabular}

Berdasarkan tabel 1 menunjukkan bahwa responden di Wilayah Kerja Puskesmas Winong I Kabupaten Pati yang berpengetahuan kurang sebanyak 5 orang
Jenis penelitian yang digunakan adalah explanatory research dengan menggunakan pendekatan metode Cross Sectional. Ruang lingkup penelitian ini termasuk dalam lingkup kesehatan ibu. Variabel independen adalah Tingkat pengetahuan, budaya dan pendapatan keluarga, sedangkan variabel dependen adalah Kurang Energi Kronis. Populasi dan sampel dalam penelitian ini adalah ibu hamil sebanyak 42 ibu hamil yang diambil dengan teknik total sampling. Instrumen yang digunakan dalam penelitian ini berupa kuesioner tentang pengetahuan, budaya dan pendapatan keluarga, serta lembar observasi kejadian KEK ibu hamil. Pengolahan data dilakukan dengan cara editing, coding, scoring dan tabulasi data. Pada penelitin ini menggunakan uji analisis Chi Square. 
Winong I Kabupaten Pati

\begin{tabular}{clcc}
\hline No. & \multicolumn{1}{c}{ Kategori Budaya } & F & $\%$ \\
\cline { 2 - 4 } 1. & Tidak Mendukung & 12 & 28,6 \\
2. & Kurang Mendukung & 25 & 59,5 \\
3. & Mendukung & 5 & 11,9 \\
\hline \multicolumn{2}{c}{ Jumlah } & 42 & 100 \\
\hline
\end{tabular}

Berdasarkan tabel 2 menunjukkan bahwa kategori budaya di Wilayah Kerja Puskesmas Winong I Kabupaten Pati yang tidak mendukung sebanyak 12 orang
(28,6\%), yang kurang mendukung sebanyak 25 orang $(59,5 \%)$ dan mendukung sebanyak 5 orang $(11,9 \%)$.

Table 3

Distribusi Frekuensi Pendapatan Keluarga Responden di Wilayah Kerja Puskesmas Winong I Kabupaten Pati

\begin{tabular}{clcc}
\hline No. & \multicolumn{1}{c}{ Pendapatan keluarga } & $\mathrm{f}$ & $\%$ \\
\hline 1 & $<437.500$ & 10 & 23,8 \\
2. & $437.500-1.000 .000$ & 23 & 54,8 \\
3. & $>1.000 .000$ & 9 & 21,4 \\
\hline
\end{tabular}

Berdasarkan tabel 3 diketahui bahwa keluarga di Wilayah Kerja Puskesmas orang $(23,8 \%)$. Yang berpendapatan Winong I Kabupaten Pati yang berpendapatan $<437.500$ sebanyak 10 $437.500-1.000 .000$ sebanyak 23 orang $(54,8 \%)$ dan yang berpendapatan > 1.000.000 sebanyak 9 orang $(21,4 \%)$.

\section{Tabel 4}

Distribusi Frekuensi KEK di Wilayah Kerja Puskesmas Winong I Kabupaten Pati

\begin{tabular}{clccc}
\hline No & & KEK & f & $\%$ \\
\hline 1 & KEK & 8 & 19 \\
2 & Normal & 34 & 81 \\
\hline & Jumlah & 42 & 100 \\
\hline
\end{tabular}

Berdasarkan tabel 4 menunjukkan sebanyak 8 orang (19\%) dan yang normal bahwa di Wilayah Kerja Puskesmas sebanyak 34 orang $(81 \%)$.

Tabel 5

Tabulasi Silang Kategori Pengetahuan dengan KEK di Wilayah Kerja Puskesmas Winong I Kabupaten Pati 


\begin{tabular}{|c|c|c|c|c|c|c|c|}
\hline \multirow{3}{*}{ No } & \multirow{3}{*}{$\begin{array}{c}\text { Kategori } \\
\text { Pengetahuan }\end{array}$} & \multicolumn{4}{|c|}{ Kejadian KEK } & \multirow{2}{*}{\multicolumn{2}{|c|}{ Total }} \\
\hline & & \multicolumn{2}{|c|}{ KEK } & \multicolumn{2}{|c|}{ Normal } & & \\
\hline & & $\mathrm{f}$ & $\%$ & $\mathrm{f}$ & $\%$ & $\mathrm{f}$ & $\%$ \\
\hline 1 & Kurang & 5 & 100 & 0 & 0 & 5 & 100 \\
\hline 2 & Sedang & 2 & 7,7 & 24 & 92,3 & 26 & 100 \\
\hline 3 & Baik & 1 & 9,1 & 10 & 90,9 & 11 & 100 \\
\hline & Jumlah & 8 & 19 & 34 & 81 & 42 & 100 \\
\hline
\end{tabular}

Berdasarkan Tabel 5 di atas responden yang mempunyai pengetahuan kurang terjadi KEK sebanyak 5 orang (100\%), dan normal sebanyak 0 orang $(0 \%)$. Responden yang mempunyai pengetahuan sedang terjadi KEK sebanyak 2 orang $(7,7 \%)$ dan normal sebanyak 24 orang (92,3\%). Responden yang mempunyai pengetahuan baik terjadi KEK sebanyak 1 orang $(9,1 \%)$ dan normal sebanyak 10 orang $(90,9 \%)$.

Hasil uji statistik dengan menggunakan chi square didapatkan hasil $p$ value $0,000<0,05$ artinya $\mathrm{Ha}$ diterima dan Ho ditolak, berarti ada hubungan antara Kategori Pengetahuan dengan KEK di Wilayah Kerja Puskesmas Winong I Kabupaten Pati.

\section{Tabel 6}

Tabulasi Silang Kategori Budaya dengan KEK di Wilayah Kerja Puskesmas Winong I Kabupaten Pati

\begin{tabular}{llccccccc}
\hline & & \multicolumn{4}{c}{ Kejadian KEK } & \multicolumn{2}{c}{ Total } \\
\cline { 3 - 6 } No & Kategori Budaya & \multicolumn{2}{c}{ KEK } & \multicolumn{2}{c}{ Normal } & & \\
& & $\mathrm{f}$ & $\%$ & $\mathrm{f}$ & $\%$ & $\mathrm{f}$ & $\%$ \\
\hline 1 & Tidak mendukung & 3 & 25 & 9 & 75 & 12 & 100 \\
2 & Kurang mendukung & 4 & 16 & 21 & 84 & 25 & 100 \\
3 & Mendukung & 1 & 20 & 4 & 80 & 5 & 100 \\
\hline & Jumlah & 8 & 19 & 34 & 81 & 42 & 100 \\
\hline
\end{tabular}

$\chi^{2}=0,429, \quad$ p value $=0,807$

Berdasarkan Tabel 6 orang $(16 \%)$, dan yang normal sebanyak menunjukkan bahwa kategori budaya yang tidak mendukung terjadiKEK sebanyak 3 orang (25\%), dan yang normal sebanyak 9 orang $(75 \%)$. Kategori budaya yang kurang 21 orang $(84 \%)$. Kategori budaya yang mendukung terjadi KEK sebanyak 1 orang $(20 \%)$ dan yang normal sebanyak 4 orang $(80 \%)$.

Hasil uji statistik dengan menggunakan chi square didapatkan 
hasil $p$ value $0,807>0,05$ artinya $\mathrm{Ha}$ ditolak dan Ho diterima, berarti tidak ada hubungan antara Kategori Budaya dengan KEK di Wilayah Kerja Puskesmas Winong I Kabupaten Pati.

Tabel 7

Tabulasi Silang Pendapatan Keluarga dengan KEK di Wilayah Kerja Puskesmas Winong I Kabupaten Pati

\begin{tabular}{ccccccccc}
\hline \multirow{2}{*}{ No } & \multirow{2}{*}{ Kategori Budaya } & \multicolumn{3}{c}{ KEK } & \multicolumn{3}{c}{ Normal } & \multicolumn{2}{c}{ Total } \\
\cline { 3 - 7 } & & $\mathrm{f}$ & $\%$ & $\mathrm{f}$ & $\%$ & $\mathrm{f}$ & $\%$ \\
1 & $<437.500$ & 5 & 50 & 5 & 50 & 10 & 100 \\
2 & $437.500-1.000 .000$ & 3 & 13 & 20 & 87 & 23 & 100 \\
3 & $>1.000 .000$ & 0 & 0 & 9 & 100 & 9 & 100 \\
\cline { 2 - 6 } & Jumlah & 8 & 19 & 34 & 81 & 42 & 100 \\
\hline
\end{tabular}

$\chi^{2}=8,869, \mathrm{p}$ value $=0,012$

Berdasarkan Tabel 7 di atas menunjukkan keluarga yang mempunyai pendapatan < 437.500 terjadi KEK sebanyak 5 orang $(50 \%)$, dan normal sebanyak 5 orang $(50 \%)$. Keluarga yang mempunyai pendapatan 437.500 1.000.000 terjadi KEK sebanyak 3 orang (13\%) dan normal sebanyak 20 orang (87\%). Keluarga yang mempunyai pendapatan > 1.000 .000 terjadi KEK

\section{PEMBAHASAN}

\section{Pengetahuan Ibu Hamil}

Pengetahuan merupakan hasil tahu dan ini terjadi setelah orang melakukan penginderaan terhadap subyek tertentu melalui panca indera manusia, yaitu penglihatan, pendengaran, penciuman, rasa dan raba (Notoatmojo, 2013).

Berdasarkan hasil penelitian diketahui bahwa ibu hamil di Wilayah Kerja sebanyak 0 orang $(0 \%)$ dan normal sebanyak 9 orang (100\%).

Hasil uji statistik dengan menggunakan chi square didapatkan hasil $p$ value $0,012<0,05$ artinya Ha diterima dan Ho ditolak, berarti ada hubungan antara Pendapatan Keluarga dengan KEK di Wilayah Kerja Puskesmas Winong I Kabupaten Pati.

Puskesmas Winong I Kabupaten Pati sebagian besar berpengetahuan sedang sebanyak 26 orang $(61,9 \%)$ dan paling sedikit berpengetahuan kurang sebanyak 5 orang $(11,9 \%)$.

Hal ini disebabkan karena ibu hamil tidak memperhatikan status gizi dan menu makanan bagi ibu hamil, mereka tidak berusaha mencari informasi tentang menu 
makanan bagi ibu hamil, walaupun banyak pendidikan SMA tapi pengetahuan tentang status gizi ibu hamil sebagian besar rendah. Hal ini didukung dengan minimnya informasi dan buku-buku tentang menu makanan untuk ibu hamil yang sampai kepada ibu balita.

Kegiatan posyandu di Puskesmas Winong I kurang melakukan penyuluhan tentang kebutuhan gizi ibu hamil. Dengan pengetahuan baik yang dimiliki ibu hamil akan semakin baik dalam menerapkan perilaku kesehatan. Puskesmas belum melakukan pembinaan secara maksimal, kegiatan posyandu hanya penimbangan, pencatatan, imunisasi dan penyuluhan kesehatan tentang kebutuhan gizi ibu hamil kurang dilakukan

\section{Budaya Ibu Hamil}

Berdasarkan hasil penelitian diketahui bahwa ibu hamil di Wilayah Kerja Puskesmas Winong I Kabupaten Pati sebagian besar mempunyai budaya kurang mendukung sebanyak 25 orang $(59,5 \%)$, dan yang mendukung sebanyak 5 orang $(11,9 \%)$.

Teori Supariasa (2012) budaya mempengaruhi ibu hamil untuk melakukan perilaku yang mendukung status gizi ibu hamil.

Budaya masyarakat di Wilayah Kerja Puskemas Winong I, sebagian besar kurang mendukung, karena mereka hanya makan seadanya, dari hasil kebun, atau budaya pantang makan ikan laut pada waktu hamil karena menyebabkan gatal-gatal. Ibu hamil tidak boleh makan makanan yang manis, padahal gula adalah sumber karbohidrat merupakan sumber energi. Budaya, akan mempengaruhi ibu untuk mengkonsumsi makanan.

\section{Pendapatan Keluarga}

Berdasarkan hasil penelitian diketahui bahwa keluarga ibu hamil di Wilayah Kerja Puskesmas Winong I Kabupaten Pati sebagian besar berpendapatan 437.5001.000.000 sebanyak 23 orang (54-,81/o) dan paling sedikit berpendapatan > 1.000 .000 sebanyak 9 orang $(21,4 \%)$.

Wilayah kerja Puskesmas Winong I merupakan daerah kecamatan, yang memungkinkan mereka berinteraksi dan mendapatkan penghasilan yang sesuai. Keluarga ibu hamil memiliki usaha di luar Jawa seperti Irian Jaya dan Kalimantan. Ibu hamil bekerja di Pabrik Kacang Garuda yang sudah menerapkan Upah Minimum Regional, sehingga cukup untuk memenuhi kebutuhan keluarga. Selain itu ibu juga bekerja swasta, pedagang dan sebagai PNS yang mendapatkan gaji yang cukup untuk memenuhi kebutuhan keluarga. Pendidikan yang memenuhi dimungkinkan ibu mendapat pekerjaan yang lebih baik sehingga penghasilannya mencukupi untuk kebutuhan keluarga.

\section{Kejadian Kurang Energi Kronik (KEK)}

Berdasarkan hasil penelitian diketahui bahwa ibu hamil di Wilayah Kerja Puskesmas Winong I Kabupaten Pati 
sebagian besar normal sebanyak 34 orang (811/6) dan yang terjadi KEK sebanyak 8 orang (19\%).

Lingkar Lengan Atas (LLA) adalah cara untuk mengetahui resiko KEK pada wanita usia subur dan ibu hamil. Ambang batas LLA bagi wanita usia subur dengan resiko Kekurangan Energi Kronis (KEK) adalah $23,5 \mathrm{~cm}$. Jika LLA $<23,5 \mathrm{~cm}$ artinya wanita tersebut mempunyai resiko KEK dan diperkirakan akan melahirkan bagi dengan berat badan lahir rendah (BBLR) (Supariasa, 2014).

Ibu hamil yang LLAnya $<23,5 \mathrm{~cm}$ mengatakan selama hamil tidak pernah memperhatikan makanannya apalagi gizinya, bahkan mereka kadang juga puasa mutih jadi hanya makan nasi saja tidak mengkonsumsi makanan yang bergizi selama hamil sedangkan responden yang LLA nya lebih dari atau sama dengan 23,5 $\mathrm{cm}$ mengatakan selama hamil mengkonsumsi nasi, sayur, lauk, buah dan ditambah susu.

Pengetahuan yang kurang dan sikap yang negatif terhadap gizi untuk ibu selama hamil dan ditambah lagi keadaan sosial ekonomi yang kurang membuat responden merasa sangat berat untuk mengkonsumsi makanan yang mengandung cukup gizi. Keadaan ini menjadikan responden kekurangan gizi yang selanjutnya ibu hamil dapat terjadi Kekurangan Energi Protein (KEK) yang ditandai dengan Lingkar Lengan Atas kurang dari $23,5 \mathrm{~cm}$. Jika kekurangan gizi pada ibu hamil te\&di sampai bayinya lahir maka diperkirakan akan melahirkan bayi dengan berat badan lahir rendah (BBLR).

\section{Hubungan Pengetahuan dengan}

\section{Kejadian Kurang Energi Kronik (KEK)}

Berdasarkan hasil penelitian diketahui bahwa hasil $p$ value $0,000<0,05$ artinya $\mathrm{Ha}$ diterima dan Ho ditolak, berarti ada hubungan antara Kategori Pengetahuan dengan KEK di Wilayah Kerja Puskesmas Winong I Kabupaten Pati.

Dari hasil penelitian diketahui bahwa ibu hamil yang Lingkar Lengan Atasnya > 23,5 cm dengan pengetahuan baik lebih banyak Sebanyak 10 Orang (90,9\%) dibandingkan dengan ibu hamil yang pengetahuannya dalam kategori cukup $(92,3 \%)$ dan kurang $(0 \%)$. Hal ini sesuai dengan teori Notoatmodjo (2013) bahwa pengetahuan merupakan salah satu faktor yang mempengaruhi perilaku kesehatan seseorang dan perilaku tersebut akan mempunyai status kesehatan seseorang dalam hal ini status gizi ibu hamil.

Responden yang mempunyai pengetahuan baik mengenai gizi yang dibutuhkan selama hamil dan akibatnya jika tidak terpenuhi maka lebih memperhatikan gizinya dari pada ibu hamil yang pengetahuannya kurang. Responden tersebut berusaha mengkonsumsi makanan yang bergizi agar tidak terjadi kekurangan gizi yang ditandai denagan LLA $<23,5 \mathrm{~cm}$. Dengan pengetahuan yang demikian ibu 
hamil akan lebih langgeng untuk selalu memperhalikan gizinya daripada yang pengetahuannya kurang, hal ini sesuai teori Notoatmodjo (2013) bahwa perilaku yang didasari oleh pengetahuan akan berlangsung lama atau langgeng dibandingkan dengan perilaku yang tidak di dasari pengetahuan. Ibu hamil yang mempunyai pengetahuan baik tentang pemenuhan gizi ibu hamil, cenderung ibu akan memenuhi kebutuhan gizinya demia pertumbuhan janin dalam kandungan.

\section{Hubungan Sosial Budaya dengan} Kejadian Kurang Energi Kronik (KEK)

Berdasarkan hasil penelitian diketahui bahwa uji statistik dengan menggunakan chi square didapatkan hasil $p$ value $0,807>$ 0,05 artinya Ha ditolak dan Ho diterima, berarti tidak ada hubungan antara Kategori Budaya dengan KEK di Wilayah Kerja Puskesmas Winong I Kabupaten Pati.

Menurut Suharjo (2013) bahwa budaya mempengaruhi ibu hamil untuk melakukan perilaku yang mendukung status gizi ibu hamil. Budaya ibu hamil yang melarang makan makanan laut karena amis sangat merugikan kebutuhan nutrisi ibu hamil. Budaya ibu hamil yang harus, minum air kelapa supaya anaknya bersih, akan mendukung nutrisi ibu hamil.

Budaya mendukung ibu hamil dalam pemenuhan gizi, maka status gizi ibu hamil akan semakin baik, sebaliknya apabila, budaya kurang mendukung maka ibu cenderung mengikuti pola makan sesuai dengan budaya adat setempat, sehingga berisiko terjadi anemia.

\section{Hubungan Pendapatan Keluarga dengan}

\section{Kejadian Kurang Energi Kronik (KEK)}

Berdasarkan hasil penelitian diketahui bahwa uji statistik dengan menggunakan chi square didapatkan hasil $p$ value $0,012<0,05$ artinya Ha diterima dan Ho ditolak, berarti ada hubungan antara Pendapatan Keluarga dengan KEK di Wilayah Kerja Puskesmas Winong I Kabupaten Pati.

Soetjiningsih (2009) menyatakan bahwa tingkat ekonomi yang rendah akan mempengaruhi asupan gizi pada seluruh anggota, keluarga, terutama pada kelompok balita dan ibu hamil sehingga, akan mempengaruhi proses pertumbuhan dan perkembangan ibu hamil dan balita yang ada dalam keluarga. Pendapatan keluarga, yang memadai akan menunjang pertumbuhan gisi ibu hamil karena, keluarga dapat menyediakan semua kebutuhan anak baik yang primer (makan, pakaian dan perumahan) maupun sekunder (rekreasi, olah raga).

Semakin tinggi pendapatan ibu Semakin tinggi pendapatan ibu hamil, ibu hamil dapat memenuhi kebutuhan gizi selama kehamilan. Dengan terpenuhinya gizi risiko terjadi anemia sangat kecil. Semakin rendah pendapatan ibu hamil, ibu hamil tidak dapat memenuhi kebutuhan gizi selama kehamilan, mereka, hanya makan seadanya tanpa meperhalikan asupan gizi, 
sehingga sangat berisiko terjadi anemia.

\section{PENUTUP}

Berdasarkan hasil penelitian dapat disimpulkan bahwa tidak ada hubungan antara Kategori Budaya dengan KEK ( $\mathrm{p}$ value $=0,867>0,05)$, ada hubungan antara tingkat pengetahuan dengan $(\mathrm{p}$ value $=0,000<0,05)$ dan ada hubungan antara Pendapatan Keluarga dengan KEK di Wilayah Kerja Puskesmas Winong I Kabupaten Pati ( $\mathrm{p}$ value $=0,012<0,05$ ) Diharapkan hasil penelitian ini dapat digunakan oleh tenaga kesehatan dalam meningkatkan penyuluhan kepada ibu hamil untuk mengkonsumsi makanan dengan menu seimbang guna memenuhi kebutuhan gizi selama hamil.

\section{DAFTAR PUSTAKA}

Arisman, MB. 2017. Gizi Dalam Kehidupan. Jakarta : Penerbit Buku Kedokteran EGC.

Budiarto, Eko. 2012. Biostatistik untuk Kedokteran dan Kesehatan Masyarakat. Jakarta : Penerbit Buku Kedokteran EGC

Depkes RI. 2012. Gizi Seimbang Menuju Hidup Sehat bagi Ibu Hamil dan Menyusui. Depkes RI, Jakarta.

Depkes RI, 2012. Makanan Sehat Balita dan Ibu Hamil. Jakarta : Depkes RI Husain, Sanjaya dan Muhilal. 2000. Rasionalisasi dan Penggunaan KMS Ibu Hamil dan LLA, Serta
Antropometri Bayi Baru Lahir. Cipanas : Kumpulan Makalah Diskusi Pakar Bidang Gizi tentang ASI-MP ASI Antropometri dan BBLR.

Notoatmojo, Soekidjo. 2013. Pendidikan dan Perilaku Kesehatan. Jakarta Penerbit Rineka, Cipta

Sugiyono, 2015. Statistik untuk Penelitian. Bandung : Alfabeta,

Supariasa, Nyoman, Dewa. 2012. Penilaian Status Gizi. Jakarta : Penerbit Buku Kedokteran EGC 